\title{
Preventivní kardiologie v praxi
}

\section{Martina Vitáskováa, Pavel Suchánekc, Jaroslava Štochlováa, Irena Houškováa, Alena Karbanováa, Irena Masákováa, Martin Kleissnerb, Martin Bláha ${ }^{b}$, Jan Benešb ${ }^{b}$ Renata Langováb, Veronika Hoškováb, Olga Řehákováb, Věra Adámkováa}

\author{
a Pracoviště preventivní kardiologie, Kardiocentrum, Institut klinické a experimentální medicíny, Praha, \\ Česká republika \\ ${ }^{b}$ Klinika kardiologie, Kardiocentrum, Institut klinické a experimentální medicíny, Praha, Česká republika \\ ' Laboratoř pro výzkum aterosklerózy, Centrum experimentální medicíny, Institut klinické a experimentální \\ medicíny, Praha, Česká republika
}

Klíčová slova:

Edukace

Oběhová zdatnost srdce

Preventivní kardiologie

\section{SOUHRN}

Cíl: Cílem rozboru získaných dat bylo posoudit, kdo a proč se edukativní akce zúčastnil, kardiovaskulární riziko účastníků a potenciální možnosti edukativních snah v kardiovaskulární prevenci do budoucna.

Metodika: Vyšetření zahrnovala stanovení koncentrace cholesterolu př́istrojem BeneCheck, respektive koncentrace glukózy přístrojem OneTouch Ultra, obojí ve vzorku kapilární krve, dále měření krevního tlaku u sedícího pacienta př́strojem Omron M6W a hodnocení oběhové zdatnosti srdce standardním výstupovým testem. Účastníci byli požádáni o zodpovězení otázek z anonymního dotazníku.

Výsledky: Hodnoty koncentrací celkového cholesterolu, respektive glukózy v kapilární krvi byly zařazeny do koncentračních rozmezí.

Celkový cholesterol v kapilární krvi: rozmezí 3-3,99 mmol/l - deset (28,6 \%) mužů a dvě $(4,4 \%)$ ženy; rozmezí 4-4,99 mmol/l - třináct (37,1 \%) mužů a patnáct (33,3 \%) žen; rozmezí 5-5,99 mmol/l - osm (22,9\%) mužů a patnáct $(33,3 \%)$ žen; rozmezí $6-6,99 \mathrm{mmol} / \mathrm{l}$ - dva $(5,7 \%)$ muži a pět $(11,1 \%)$ žen; rozmezí $8-8,99 \mathrm{mmol} / \mathrm{l}$ - jedna $(2,2 \%)$ žena.

Glukóza v kapilární krvi: rozmezí 4-4,99 mmol/l - třináct $(37,1 \%)$ mužů a čtrnáct (32,6 \%) žen; rozmezí 5-5,99 mmol/l - patnáct (42,9\%) mužů a šestnáct (37,2 \%) žen; rozmezí 6-6,99 mmol/l - pět (14,3\%) mužů a devět $(20,9 \%)$ žen; rozmezí $7-7,99$ mmol - jeden $(2,9 \%)$ muž a dvě $(4,7 \%)$ ženy; koncentrace glukózy mimo uvedená koncentrační rozmezí byly stanoveny u dvou žen $(3,8 \mathrm{mmol} / \mathrm{l}$ a $10,9 \mathrm{mmol} / \mathrm{l})$ a jednoho muže $(11,7 \mathrm{mmol} / \mathrm{l})$, přičemž oba zúčastnění s nadlimitní hodnotou glykemie se léčili pro známý diabetes mellitus. Celkem u dvanácti účastníkủ byly naměřeny hodnoty krevního tlaku svědčíí pro arteriální hypertenzi, u tři z nich šlo o léčenou arteriální hypertenzi, a tudíž nedostatečně kompenzovanou, u zbývajících devíti šlo o první záchyt arteriální hypertenze.

Cigarety kouřilo 11 (30,6 \%) z 36 mužů, respektive 8 (15,7 \%) z 51 žen. Rozmezí počtu cigaret vykouřených za den (3-40 cig./den, respektive 3-30 cig./den) ani průměrný počet cigaret (17 cig./den, respektive 15,7 cig./ den) se mezi muži a ženami významněji nelišily.

U většiny zúčastněných byla zjištěna podprůměrná (deset mužů, šest žen), respektive průměrná (šest mužůu, deset žen) oběhová zdatnost srdce.

Závěr: Koncentrace celkového cholesterolu, respektive glukózy v kapilární krvi se orientačně pohybovaly v normálním rozmezí hodnot nebo lehce nad jeho horní hranicí. Oběhová zdatnost srdce mužủ a žen byla většinou průměrná až podprůměrná. Odhadem nebyl ve všech sledovaných parametrech mezi muži a ženami významný rozdíl kromě kouření cigaret.

Cílovými oblastmi pro preventivní intervence se ukázaly být oběhová zdatnost srdce, která prokazatelně negativně koreluje s parametry metabolismu glycidů, a kouření cigaret.

Adresa: MUDr. Martina Vitásková, CSc., Pracoviště preventivní kardiologie, Kardiocentrum, Institut klinické a experimentální medicíny, Vídeňská 1958/9, 14021 Praha 4, e-mail: martina.vitaskova@ikem.cz 


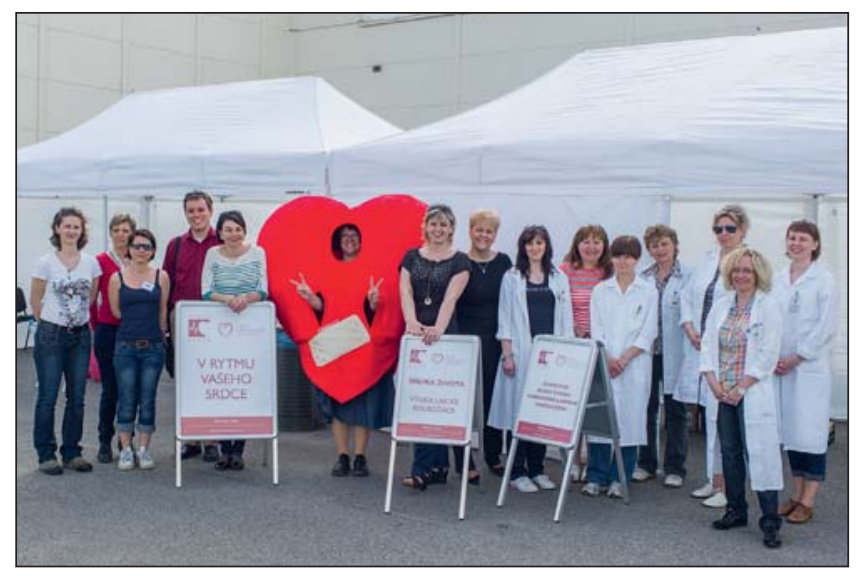

Obr. 1 - „Preventivní kardiologie v praxi“ - většina zúčastněných pracovníků Pracoviště preventivní kardiologie, Kliniky kardiologie a pořádající společnosti nadace Rytmus srdce, Klinika kardiologie (Kardiocentrum, IKEM, Praha)

\section{Úvod}

Dne 4. května 2013 se v rámci XXI. výročního sjezdu České kardiologické společnosti konala pod záštitou České kardiologické společnosti edukativní akce „Zaposlouchejte se do rytmu svého srdce!“ (obr. 1). Zájemci si mohli nechat změřit krevní tlak, koncentraci celkového cholesterolu a glukózy v kapilární krvi a výsledky pak konzultovat s lékařem na jednom ze stanovišt'. Na ostatních stanovištích probíhalo hodnocení oběhové zdatnosti srdce a zhotovení základního EKG záznamu s jeho interpretací. Edukativní část dále doplňovala instruktáž v resuscitaci a informační stánek týkající se racionálního stravování a zdravého životního stylu obecně.

$\checkmark$ době, kdy jsou hlavní příčinou úmrtí v civilizovaném světě kardiovaskulární onemocnění, se péče o zdravotní stav stává vlastním zájmem jednotlivce, ne pouze předmětem snažení lékaře. Níže uvedený rozbor souboru zájemců o vyšetření, získaných výsledků a orientačně jejich motivací $k$ vyšetření dává možnost posoudit, kdo a proč se vyšetření z vlastní vưle účastní, jaký je nejčastěji jeho zdravotní stav, a nastiňuje tak potenciální možnosti dalšího směřování edukativních snah do budoucna.

\section{Prováděná vyšetřeni}

Soubor vyšetřených tvořili dobrovolní zájemci, u kterých byla provedena antropometrická vyšetření, změření krevního tlaku za daných podmínek, stanovení koncentrace celkového cholesterolu a glukózy z kapilární krve, eduka-

\begin{tabular}{|l|l|}
\hline \multicolumn{2}{|l|}{ Tabulka 1 - Hodnocení stupně zdatnosti dle hodnoty indexu zdatnosti } \\
\hline Index zdatnosti & Stupeň zdatnosti \\
\hline$<80$ & Podprůměrná zdatnost \\
\hline $80-99$ & Průměrná zdatnost \\
\hline $100-119$ & Dobrá zdatnost \\
\hline $120-139$ & Velmi dobrá zdatnost \\
\hline$>139$ & Výborná zdatnost \\
\hline
\end{tabular}

ce rizikových faktorů kardiovaskulárních chorob, stanovení individuálního rizika a vyhotovení základního EKG záznamu. Zájemci si mohli vyzkoušet laickou první pomoc, včetně zevní srdeční masáže.

Další možností bylo zjištění oběhové zdatnosti srdce standardním výstupovým testem, modifikovaným podle Institutu tělesné výchovy a sportu v Praze.

\section{Metodika}

\section{Stanovení koncentrace cholesterolu ve vzorku kapilární krve}

Aktuální koncentrace celkového cholesterolu ( $\mathrm{mmol} / \mathrm{l}$ ) byla stanovena v kapilární krvi přístrojem BeneCheck.

\section{Stanovení koncentrace glukózy ve vzorku kapilární krve}

Koncentrace glukózy v kapilární krvi (mmol/l) byla stanovena prístrojem OneTouch Ultra.

\section{Měření krevního tlaku}

Krevní tlak byl měřen u sedícího pacienta přístrojem Omron M6W. Počty měření se lišily dle stanoviště a jeho vytíženosti v daný okamžik, a proto se počet měření krevního tlaku na účastníka pohyboval v rozmezí jednoho až tří. Někteří zúčastnění z analyzovaného souboru stanoviště měření krevního tlaku neabsolvovali.

\section{Hodnocení oběhové zdatnosti srdce - standardní výstupový test}

Při hodnocení oběhové zdatnosti srdce vystupoval vyšetřovaný jedinec po dobu 240 sekund na podložku o výšce $50 \mathrm{~cm}$ u mužů, respektive $40 \mathrm{~cm}$ u žen, s frekvencí 30 výstupů za minutu. Tepová frekvence byla měřena po celou dobu, zaznamenána byla na konci výstupové části.

Po uplynutí 240 sekund následovala fáze zklidnění s opakovanými měřeními tepové frekvence za 60 s (S1), 120 s (S2) a 180 s (S3) od ukončení cvičení.

Ze získaných hodnot byl dle níže uvedeného vzorce vypočítán index zdatnosti a na základě jeho hodnoty byla zdatnost rozdělena do skupin podprưměrná, průměrná, dobrá, velmi dobrá a výborná zdatnost (viz tabulku 1).

$$
\text { Index zdatnosti }=\frac{\text { doba trvání cvičení }(\mathrm{s}) \times 100}{\text { součet } \mathrm{S} 1+\mathrm{S} 2+\mathrm{S} 3}
$$

\section{Výsledky}

Zájem návštěvníků nákupního centra Olympia o nabízený program zobrazuje tabulka 2 . Z uvedených údajů vyplývá, že pouze 73 \% (87) z těch, kterým byly stanoveny koncentrace cholesterolu a glukózy v kapilární krvi (119), konzultovalo dále tyto výsledky s lékařem.

Na všech uvedených stanovištích (odběry kapilární krve a měření krevního tlaku, konzultace lékaře, vyhotovení základního EKG záznamu s měřením krevního tlaku) převažovaly mezi zúčastněnými ženy. Největší zájem byl o stanovení laboratorních parametrů a změření krevního tlaku, následovalo vyhotovení základního EKG záznamu 


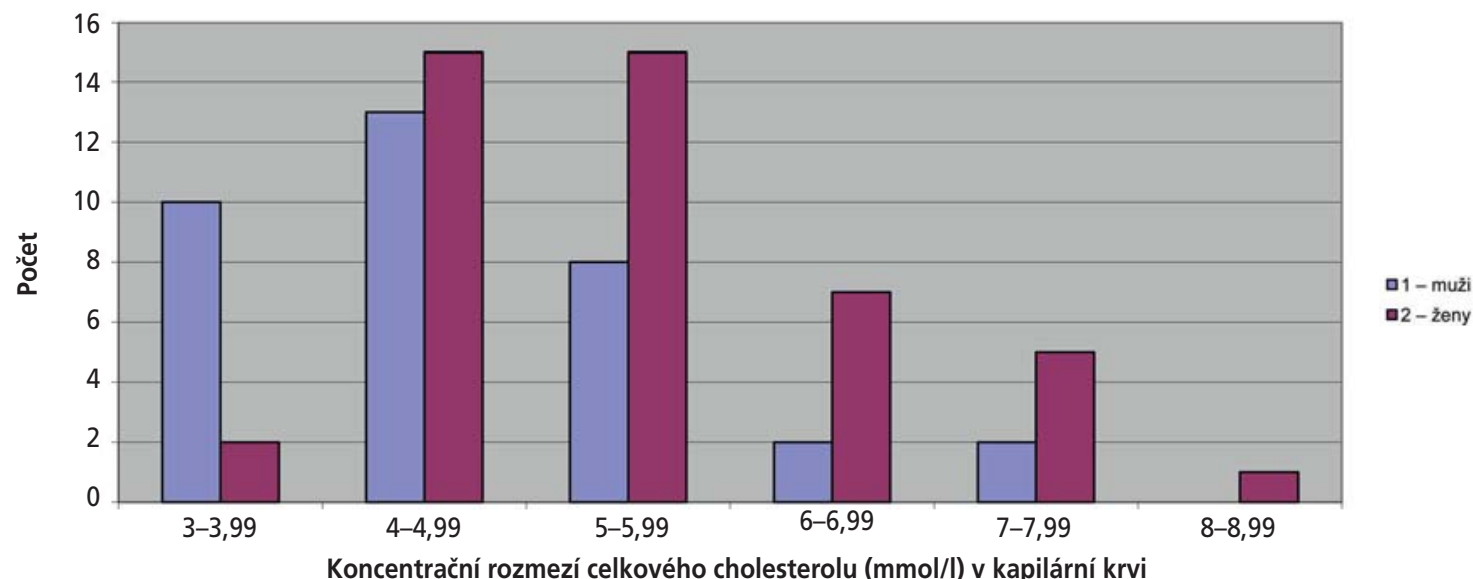

Obr. 2 - Koncentrace celkového cholesterolu v kapilární krvi

s měřením krevního tlaku, konzultace lékaře a nakonec hodnocení oběhové zdatnosti srdce.

\section{Stanovení koncentrace celkového cholesterolu, respektive glukózy (mmol/l) v kapilární krvi}

Celkem si nechalo stanovit koncentraci celkového cholesterolu a glukózy v kapilární krvi 119 zájemců, 53 (44,5%) mužů a 66 (55,5 \%) žen.

Odebraná krev nesplňovala standardní odběrové podmínky, lidé nebyli nalačno, mnozí právě poobědvali. Vzhledem $\mathrm{k}$ tomuto faktu jsme u těchto parametrů nestanovovali průměrnou hodnotu ani směrodatnou odchylku, výsledky jsou prezentovány formou sloupcového grafu jako počet pro jednotlivá koncentrační rozmezí.

Rozložení mužů a žen dle jednotlivých koncentračních rozmezí celkového cholesterolu znázorňuje obrázek 2 . Do koncentračního rozmezí 3-3,99 $\mathrm{mmol} / \mathrm{l}$ spadalo deset $(28,6 \%)$ mužů a dvě $(4,4 \%)$ ženy, do rozmezí 4-4,99 $\mathrm{mmol} / \mathrm{l}$ pak třináct $(37,1 \%)$ mužů a patnáct $(33,3 \%)$ žen, do rozmezí 5-5,99 mmol/l patřilo osm (22,9 \%) mužů a patnáct $(33,3 \%)$ žen, skupinu v rozmezí 6-6,99 mmol/l tvořili dva $(5,7 \%)$ muži a pět $(11,1 \%)$ žen a do rozmezí $8-8,99 \mathrm{mmol} / \mathrm{l}$ patřila jedna $(2,2 \%)$ žena.

Obrázek 3 zobrazuje hodnoty koncentrace glukózy (mmol/l) v kapilární krvi. V koncentračním rozmezí 4-4,99 mmol// bylo třináct $(37,1 \%)$ mužů, respektive čtrnáct $(32,6 \%)$ žen, následováno patnácti $(42,9 \%)$ muži a šestnácti $(37,2 \%)$ ženami ve skupině 5-5,99 mmol/l, do koncentračního rozmezí 6-6,99 mmol/l patřilo pět $(14,3 \%)$ mužů a devět $(20,9 \%)$ žen, glykemie v rozmezí 7-7,99 mmol byla naměřena u jednoho (2,9 \%) muže a dvou $(4,7 \%)$ žen. Koncentrace glukózy mimo uvedená koncentrační rozmezí byly stanoveny u dvou žen (3,8 a 10,9 mmol/l) a jednoho muže $(11,7 \mathrm{mmol} / \mathrm{l})$, přičemž se oba zúčastnění s nadlimitními koncentracemi léčili pro známý diabetes mellitus. Koncentrace glukózy u třetího již známého diabetika v našem souboru svědčila o dobré kompenzaci tohoto onemocnění.

\section{Měření krevního tlaku $(\mathrm{mm} \mathrm{Hg})$}

Alespoň jednou byl krevní tlak změřen u 83 účastníků. Vyhodnocení vycházelo z jednoho měření nebo z průměru dvou, respektive tří měření. Celkem u dvanácti účastníků byly naměřeny hodnoty krevního tlaku velmi pravděpodobně svědčíi pro arteriální hypertenzi, ta byla u tři z nich již známá a léčená,

\begin{tabular}{l|l|l|l|}
\hline Tabulka 2 - Počty hodnocených na jednotlivých stanovištích \\
\hline Stanoviště & Muži & Ženy & Celkem \\
\hline $\begin{array}{l}\text { Odběry kapilární krve } \\
\text { a měření krevního tlaku }\end{array}$ & 53 & 66 & 119 \\
\hline $\begin{array}{l}\text { Konzultace lékaře } \\
44,5 \%\end{array}$ & 36 & $55,5 \%$ & \\
\hline $\begin{array}{l}\text { Vyhotovení základního } \\
\text { EKG záznamu a základy } \\
\text { resuscitace }\end{array}$ & $41 \%$ & $59 \%$ & 87 \\
\hline $\begin{array}{l}\text { Hodnocení oběhové } \\
\text { zdatnosti srdce }\end{array}$ & $46 \%$ & 56 & 102 \\
\hline & 18 & 22 & 40 \\
\hline & $45 \%$ & $55 \%$ & \\
\hline
\end{tabular}

\begin{tabular}{|l|l|l|l|}
\hline \multicolumn{3}{|l}{ Tabulka 3 - Věkové rozvrstvení konzultujících } \\
\hline Věk & Muži & Ženy & Celkem \\
\hline$\leq 20$ & 3 & 1 & 4 \\
\hline $21-30$ & 12 & 13 & 25 \\
\hline $31-40$ & 7 & 9 & 16 \\
\hline $41-50$ & 4 & 8 & 12 \\
\hline $51-60$ & 4 & 10 & 14 \\
\hline $61-70$ & 2 & 10 & 12 \\
\hline $71-80$ & 1 & - & 1 \\
\hline Celkem & 33 & 51 & 84 \\
\hline
\end{tabular}

\begin{tabular}{l|l|l|}
\begin{tabular}{l} 
Tabulka 4 - Body mass index \\
\hline BMI
\end{tabular} & Muži & Ženy \\
\hline$<18,5$ (podváha) & 2 & 1 \\
\hline $18,5-24,99$ (optimální váha) & 26 & 12 \\
\hline $25-29,99$ (nadváha) & 14 & 18 \\
\hline $30-34,99$ (obezita 1. stupně) & 5 & 5 \\
\hline $35-39,99$ (obezita 2. stupně) & 1 & - \\
\hline$>40$ (obezita 3. stupně) & - & - \\
\hline Celkem & 48 & 36 \\
\hline
\end{tabular}




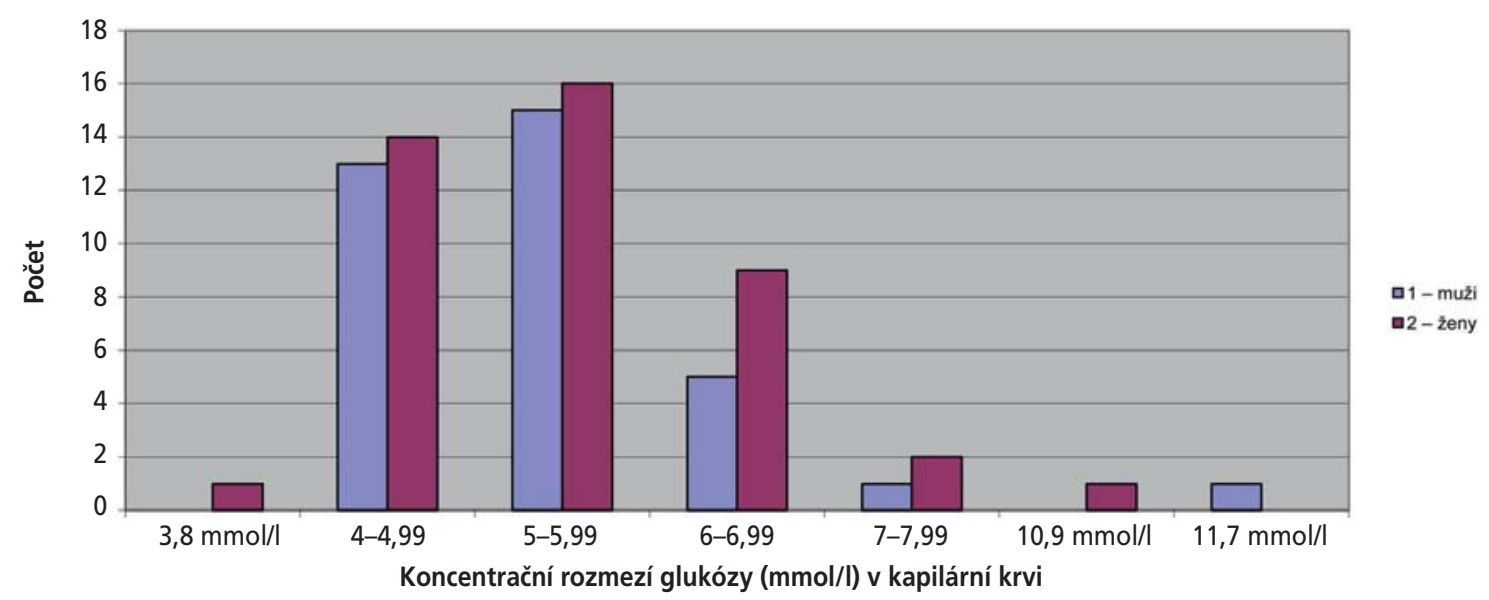

Obr. 3 - Koncentrace glukózy v kapilární krvi

a tudíž nedostatečně kompenzovaná, u zbývajících devíti šlo o první záchyt arteriální hypertenze a byla jim doporučena návštěva praktického lékaře. Šest z devíti pro arteriální hypertenzi již léčených účastníků mělo krevní tlak dobře kompenzovaný.

\section{Konzultace lékařu Pracoviště preventivní kardiologie IKEM}

O konzultaci zjištěných laboratorních výsledků v kontextu přidružených onemocnění, věku a životního stylu projevilo zájem 87 účastníků, 36 mužů (41 \%) a 51 žen (59 \%).

Nejvíc zájemců patřilo do věkové kategorie 21 až 30 let, následované kategorií 31 až 40 let, počty zúčastně-

\begin{tabular}{|l|l|l|}
\hline \multicolumn{3}{|l|}{ Tabulka 5 - Vyhodnocení indexu zdatnosti u mužů a žen } \\
\hline Index zdatnosti & Muži & Ženy \\
\hline < 80 (podprůměrná zdatnost) & 10 & 6 \\
\hline 80-99 (průměrná zdatnost) & 6 & 10 \\
\hline $100-119$ (dobrá zdatnost) & 2 & 4 \\
\hline $120-139$ (velmi dobrá zdatnost) & 0 & 2 \\
\hline$>139$ (výborná zdatnost) & 0 & 0 \\
\hline Celkem & 18 & 22 \\
\hline
\end{tabular}

\begin{tabular}{l|l|l|}
$\begin{array}{l}\text { Tabulka } 6 \text { - Onemocnění kardiovaskulárního systému } \\
\text { a diabetes mellitus }\end{array}$ & 1 - muži & 2 - ženy \\
\hline & 1 & 1 \\
\hline ICHS & & \\
\hline ICHDK & 1 & 1 \\
\hline IM/PCI & & \\
\hline CMP & & 6 \\
\hline ATS & 3 & 2 \\
\hline AH & 1 & \\
\hline DM & 1 & \\
\hline
\end{tabular}

AH - arteriální hypertenze; ATS - jiná manifestace aterosklerózy; CMP - cévní mozková príhoda; DM - diabetes mellitus; ICHDK - ischemická choroba dolních končetin; ICHS - ischemická choroba srdeční; IM/PCI - infarkt myokardu/perkutánní koronární intervence. ných v ostatních skupinách dle věku uvádí tabulka 3. Tři ze zúčastněných svůj věk neuvedli.

Výšku a hmotnost pacienti uváděli, tyto hodnoty nebyly měřeny. U 84 zúčastněných ( 48 mužů a 36 žen) bylo možné stanovit body mass index (BMI). Dva muži měli podváhu, 26 mužů patřilo do skupiny optimální váhy, nadváha byla na základě uvedených údajů přiřazena 14 mužưm, u pěti mužů šlo o obezitu 1. stupně a u jednoho muže pak o obezitu 2. stupně.

Podváhu měla jedna žena, optimální váhu 12 žen, nadváhu 18 žen a pět žen obezitu 1. stupně (tabulka 4, obr. 4).

\section{Hodnocení oběhové zdatnosti srdce}

Hodnocení oběhové zdatnosti srdce se zúčastnilo 40 zájemců, 18 mužư a 22 žen. U většiny byla zjištěna podprůměrná (deset mužů, šest žen), respektive průměrná (šest mužů, deset žen) zdatnost. Dobrá oběhová zdatnost srdce byla zjištěna u dvou mužů a čtyř žen, u dvou žen byla zdatnost velmi dobrá, výbornou zdatnost neprokázal nikdo (tabulka 5).

\section{Kouření cigaret}

Kouřilo 11 z 36 mužů (30,6 \%), počet cigaret vykouřených za den se pohyboval v rozmezí 3-40 cigaret/den, v průměru 17 cigaret/den. Žen kouřilo 8 z 51 (15,7 \%), v rozmezí 3-30 cigaret/den, v průměru 15,7 cigarety/den. Z bývalých kuřáků bylo osm mužů a devět žen (tabulka 6).

\section{Známá a léčená onemocnění}

$Z$ celkového počtu 87 respondentů neznalo nebo neuvedlo data o onemocněních kardiovaskulárního systému nebo diabetes mellitus celkem šest (čtyři muži ze 36, respektive dvě ženy z 51), podrobnosti o svých přidružených chorobách uvedly čtyři ženy.

Známou a léčenou arteriální hypertenzi uvedli tři muži, respektive šest žen, známý diabetes mellitus pak jeden muž a dvě ženy (tabulka 6 ). Obecně bylo povědomí o zdravotním stavu spíše horší.

\section{Diskuse}

Ve světovém písemnictví Ize v současné době nalézt řadu pečlivě připravených, randomizovaných a statisticky so- 


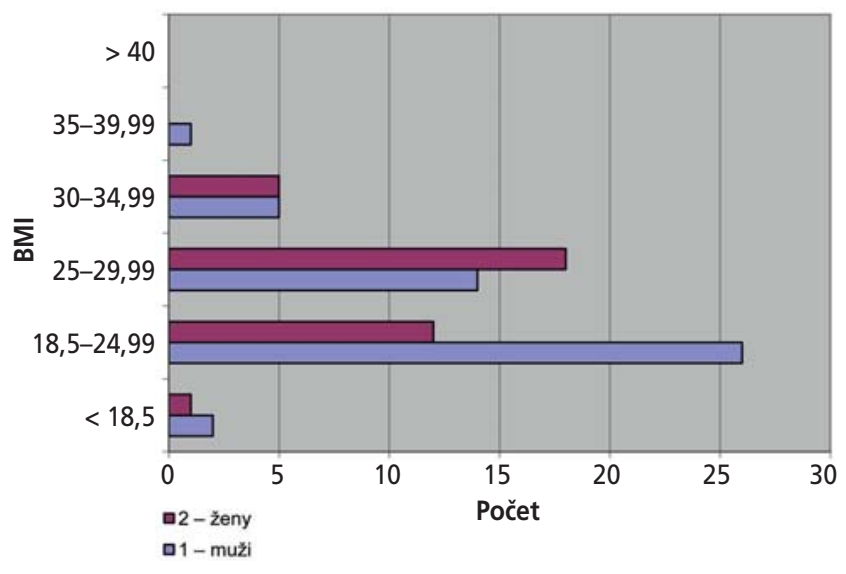

Obr. 4 - Hodnota BMI u hodnocených mužů (1) a žen (2)

fistikovaně vyhodnocených populačních studií, průřezových, retrospektivních či prospektivních, které jsou zaměřeny na rizikové faktory kardiovaskulárních onemocnění. Tyto studie se týkají náhodně vybraných skupin jedinců nebo naopak cíleně sestavených a jednoznačně charakterizovaných souborů. Podobné byly provedeny i na našem pracovišti [1,2].

Námi prezentované hodnocení zahrnovalo všechny návštěvníky nákupního centra Olympia, kteří sami projevili zájem o orientační laboratorní vyšetření, změření krevního tlaku, zhotovení základního EKG záznamu, konzultaci získaných výsledků, nácvik laické první pomoci, včetně zevní srdeční masáže, případně zjištění oběhové zdatnosti srdce. Orientačně bylo možné posoudit jejich motivaci.

Během edukativní akce "Zaposlouchejte se do rytmu svého srdce!" byl největši zájem o změření krevního tlaku a stanovení koncentrace celkového cholesterolu a glukózy v kapilární krvi, 27 \% zúčastněných dále své výsledky nekonzultovalo, 73 \% pak přešlo i ke stanovišti konzultujícího lékaře. $\mathrm{Na}$ všech stanovištích převažovaly mezi zájemci ženy. Povědomí o zdravotním stavu bylo obecně spíše horší.

V rakouské studii z roku 2012, která byla založena na anonymních dotaznících vyplněných náhodně vybranými jedinci, vědělo $75 \%$ respondentů bez rozdílu pohlaví, že hlavní př́činou úmrtí v Rakousku jsou kardiovaskulární onemocnění, znalost rizikových faktorů byla u obou pohlaví stejně nedostatečná a více než polovina respondentů své kardiovaskulární riziko podhodnotila, přičemž se toto zjištění týkalo více žen (56,4 \% vs. 52,7 \%) [3].

$\checkmark$ námi hodnoceném souboru se většina stanovených koncentrací celkového cholesterolu, respektive glukózy v kapilární krvi u mužů i žen dala odhadem zařadit spiše do normálního rozmezí hodnot nebo těsně nad horní hranici normy pro daná vyšetření, a to navzdory nedodržení standardních podmínek pro krevní odběry metabolických parametrů (nelačnění). Ty jsou v obdobných průzkumech dodržovány [1]. BMI se u mužů i žen nejčastěji pohyboval v rozmezí 18,5-29,99, tj. optimální váha a nadváha, a nejvíce zúčastěných mužủ i žen patřilo do věkové kategorie 21-40 let.

Lze tedy konstatovat, že mezi zájemci o celou naši edukativní akci nebyli ti jedinci, kterých se to týkalo nejvíce a kteří své kardiovaskulární riziko podhodnotili. Bud' zcela tím, že se vůbec nedostavili, protože to nepovažovali za nutné, nebo alespoň z části, protože se spokojili s pouhými výsledky a dál je nekonzultovali (27\% respondentů). Většina zúčastněných také spadala do mladších věkových skupin, a tudíž považovaných za zdravější.

Oběhová zdatnost srdce byla u mužů i žen nejčastěji průměrná až podprůměrná, dobrá oběhová zdatnost srdce byla konstatována u dvou mužů, respektive čtyř žen, velmi dobrá oběhová zdatnost srdce u dvou žen, výborná oběhová zdatnost srdce pak u žádného $z$ testovaných.

Nízká oběhová zdatnost byla již dříve zjištěna u jedinců s vyšší glykemií nalačno nebo s diabetes mellitus 2. typu [4]. Dále byla prokázána souvislost nízké oběhové zdatnosti s rozvojem diabetes mellitus u nediabetických pacientů $[5,6]$ a prokázána byla i reverzní korelace mezi oběhovou zdatností srdce a inzulinovou rezistencí [7].

Motivace ke kardiovaskulární prevenci byla u návštěvníků nákupního centra Olympia různá. Ženy v očekávání príchodu potomka privedly své partnery, aby aspoň orientačně "prověřily" jejich zdravotní stav, skupinka romských dospívajících se trumfovala, kdo z nich začal kouřit v mladším věku, respektive, kdo v současnosti vykouří víc cigaret za den. Nakupující, kteří svou kardiovaskulární diagnózu již znali a byli pro ni sledováni, mnohdy u renomovaných profesorů, si přišli ověřit svůj zdravotní stav kompenzovaný léčbou. Těch však bylo jen pár.

Vyšetřen byl jeden rakouský občan na výletě za nákupy v Brně, který ve své domovině delší dobu odkládal návštěvu lékaře. Opakovanými stanoveními mu byla zjištěna glykemie těsně nad $20 \mathrm{mmol} / \mathrm{l}$. Muži byla vysvětlena závažnost jeho stavu a byl odeslán do nejbližší nemocnice. Do hodnoceného souboru zařazen nebyl.

Na své cestě se zastavili i sportovci, kteří sesedli z kol. Někteří z nich se utvrdili ve vědomí o svém dobrém zdravotním stavu, spokojeně nasedli a šlápli do pedálů. Jiní však byli překvapeni vy̌šími koncentracemi celkového cholesterolu nebo vyšší glykemií a byla jim doporučena laboratorní vyšetření za standardních odběrových podmínek u praktického lékaře.

Výše uvedená fakta jsou opět v souladu s již citovaným rakouským hodnocením. $V$ našem souboru se prijímání preventivních opatření týkalo rodinných př́slušníků vyšetřených zájemkyň (těhotné ženy a jejich partneři) a i účastníci naší akce měli sklon kardiovaskulární rizikové faktory a svá onemocnění podhodnocovat a zlehčovat (trumfující se dospívající, rakouský občan s opakovaně zjištěnou hyperglykemií a zmínění sportovci s nadlimitními hodnotami cholesterolu, respektive glukózy v kapilární krvi).

\section{Závěry}

Lze konstatovat, že nabídku zhodnocení kardiovaskulárního rizika využili převážně občané v produktivním věku mezi 21 a 40 lety, tedy mladší jedinci, a více než čtvrtině z nich postačovaly výsledky měření, další možnosti konzultovat je prímo na místě nevyužili.

Větší zájem o všechna nabízená vyšetření, hodnocení zdravotního stavu i o nácvik resuscitace projevily ženy.

Zúčastnění muži i ženy měli dle BMI většinou optimální váhu nebo nadváhu, koncentrace celkového cholesterolu, 
respektive glukózy se orientačně pohybovaly v normálním rozmezí hodnot nebo lehce nad jeho horní hranicí, oběhová zdatnost srdce mužů a žen byla většinou průměrná až podprůměrná. Odhadem nebyl ve všech sledovaných parametrech mezi muži a ženami významný rozdíl kromě kouření cigaret.

Kompenzace již známých a léčených arteriálních hypertenzí, respektive diabetu nebyla vždy uspokojivá.

Největšími cílovými oblastmi pro preventivní intervence se ukázaly být průměrná až podprůměrná oběhová zdatnost srdce, která prokazatelně negativně koreluje s parametry metabolismus glycidů, a dále kouření cigaret, a to více u mužů.

Poděkování patrí paní Mgr. Pavle Krištofové z pořádající nadace Rytmus srdce, Klinika kardiologie, IKEM za prípravu jednotlivých stanovišt' a bezproblémový průběh celé akce.

\section{Literatura}

[1] R. Cífková, Z. Škodová, J. Bruthans, et al., Longitudinal trends in major cardiovascular risk factors in the Czech population between 1985 and 2007/8. Czech MONICA and Czech post-MONICA, Atherosclerosis 211 (2) (2010) 676-681.
[2] Z. Škodová, R. Cífková, V. Adámková, et al., Development of smoking habits in the population of the Czech Republic from 1985 to 1997/98, Časopis lékařů českých 139 (5) (2000) 143-147.

[3] T. Haidinger, M. Zweimüller, L. Stütz, et al., Effect of gender on awareness of cardiovascular risk factors, preventive action taken, and barriers to cardiovascular health in a group of Austrian subjects, Gender Medicine 9 (2) (2012) 94-102.

[4] M. Wei, L.W. Gibbons, T.L. Mitchell, et al., The association between cardiorespiratory fitness and impaired fasting glucose and type 2 diabetes mellitus in men, Annals of Internal Medicine 130 (1999) 89-96.

[5] S.S. Sawada, I.M. Lee, T. Muto, et al., Cardiorespiratory fitness and the incidence of type 2 diabetes: prospective study of Japanese men, Diabetes Care 26 (2003) 2918-2922.

[6] D.C. Lee, X. Sui, T.S. Church, et al., Associations of cardiorespiratory fitness and obesity with risks of impaired fasting glucose and type 2 diabetes in men, Diabetes Care 32 (2009) 257-262.

[7] E.H. Jun, B.Y. Choi, D.C. Lee, et al., Cardiopulmonary fitness is independently associated with insulin resistance in non-diabetes mellitus patients of a university hospital in Korea, Korean Journal of Family Medicine 34 (2013) 139-144. 